\begin{abstract}
References
1. 1 try yenale "Ukrainian Folkmodern 2009" (2009). Chernivci: TOV «Druk Art», 22, 32 [in Ukrainian].

2. ART-AKT. Second All-Ukrainian Triennial of Abstract Art. (2013). Chernivci: DrukArt, 28 [in Ukrainian].

3. ART-AKT. The first all-Ukrainian triennial of abstract art. (2010). Chernivci: DrukArt, 14, 38 [in Ukrainian].

4. ART-AKT. Third All-Ukrainian Triennial of Abstract Art. (2016). Chernivci: DrukArt, 3 [in Ukrainian].

5. Mishchenko, I. (2002). Artem Prysjazhnjuk. Khotyn Wanderer. Chernivci: Zoloti lytavry, 134-137 [in Ukraini-

an].

6. All-Ukrainian Exhibition of Fine Arts, dedicated to the 70th anniversary of Ivan Mykolaichuk. (n.d.). Chernivci, 36, 39 [in Ukrainian].

7. All-Ukrainian Art Exhibition "Picturesque Ukraine" (2009). Chernivci, 8, 20 [in Ukrainian].

8. Bukovina Art: Catalog. (2004). Chernivci [in Ukrainian].

an].

9. Bukovina Artists. Dughajeva, T. \& Mishchenko, I. (Eds.). (1998). Vol. 1. Chernivci: Zoloti litavry [in UkrainiUkrainian].

10. The first all-Ukrainian triennial of "non-relevant" art "PURE." (2011). Chernivci: TOV «DrukArt», 20, 36 [in
\end{abstract}

Стаття надійшла до редакції 04.11.2019 p. Прийнято до публікації 29.11.2019 р.

УДК $7.048: 7.035 .93$

\author{
Оборська Світлана Валентинівна \\ кандидат мистецтвознавства, доцент \\ Київського національного університету \\ культури і мистецтв \\ ORCID 0000-0003-3148-6325 \\ lychia0801@gmail.com
}

\title{
СПЕЦИФІКА ОРНАМЕНТАЛЬНОЇ СТИЛІЗАЦІЇ ДЕКОРУ СТИЛЮ МОДЕРН
}

\begin{abstract}
Мета статті - проаналізувати символічне значення зооморфних, фрлороморфних, орнітоморфних та інсектоморфних мотивів декору стилю модерн, виявити специфіку орнаментальної стилізації. Методи дослідження. У статті застосовано системно-історичний метод дослідження (для осмислення специфіки орнаментальної стилізації в розвитку), системного аналізу (орнамент декору стилю модерн розглядається як частина знакової системи), а також методи класифікації та порівняльного аналізу (використано при вивченні візуального матеріалу). Наукова новизна. Проаналізовано орнаментальні мотиви декору стилю модерн; визначено передумови виникнення та розвитку флороморфного і геометричного орнаменту, принципи стилізації орнаментальних образів та їх символіку. Висновки. Новаторство образів превалювало в творчості художників модерністів, які розробили новий колорит, форму, фактуру, а головне - унікальний орнамент, що став найхарактернішою ознакою стилю. Флороморфні, зооморфні, орнітоморфні, інсектоморфні, антропоморфні та геометричні мотиви, що вирізнялися відносною образністю та алегорією стають провідною тематикою орнаментики модерну, осмислюючись як система символів, що передає світ нереальний, дивовижний та прекрасний.
\end{abstract}

Ключові слова: модерн, стилізація, орнаментика, флороморфні та зооморфні мотиви, символіка, декор.

Оборская Светлана Валентиновна, кандидат искусствоведения, доцент Киевского национального университета культуры и искусств

Специфика орнаментальной стилизации декора стиля модерн

Цель статьи - проанализировать символическое значение зооморфных, флороморфных, орнитоморфных и инсектоморфных мотивов декора стиля модерн, выявить специфику орнаментальной стилизации. Методы исследования. В статье применены системно-исторический метод исследования (для осмысления специфики орнаментальной стилизации в развитии), системного анализа (орнамент декора стиля модерн рассматривается как часть знаковой системы), а также методы классификации и сравнительного анализа (использовано при изучении визуального материала). Научная новизна. Проанализированы орнаментальные мотивы декора стиля модерн; определены предпосылки возникновения и развития фрлороморфного и геометрического орнамента, принципы стилизации орнаментальных образов и их символика. Выводы. Новаторство образов превалировало в творчестве художников модернистов, которые разработали новый колорит, форму, фрактуру, а главное - уникальный орнамент, который стал характерным признаком стиля. Флороморфные, зооморфные, орнитоморфные, инсектоморфные, антропоморфные и геометрические мотивы, которые отличались относительной образностью и аллегорией, становятся ведущей темой орнаментики модерна, осмысливаясь как система символов, что передает мир нереальный, удивительный и прекрасный.

Ключевые слова: модерн, стилизация, орнаментика, флороморфные и зооморфные мотивы, символика, декор.

Obskaya Svetlana, Candidate of Arts, Associate Professor Kyiv National Culture and Arts University The specifics of the ornamental stylization of Art Nouveau decor

(C) Оборська С. В., 2020 
The purpose of the article is to analyze the symbolic meaning of the zoomorphic, phoromorphic, ornithomorphic and insectomorphic motifs of the Art Nouveau decor, to reveal the specifics of ornamental stylization. Methodology. The article applied the system-historical method of research (for understanding the specifics of ornamental stylization in development), system analysis (ornament of modern style is considered as part of a sign system), as well as methods of classification and comparative analysis (used in the study of visual material). Scientific novelty. The ornamental motifs of the Art Nouveau décor are analyzed; the prerequisites for the emergence and development of the floral and geometric ornament, the principles of stylization of ornamental images and their symbolism are determined. Conclusions. The innovation of images prevailed in the works of modernist artists, who developed a new color, shape, texture, and most importantly - a unique ornament, which became a characteristic feature of the style. Floromorphic, zoomorphic, ornithomorphic, insectomorphic, anthropomorphic and geometric motifs, which were distinguished by relative figurativeness and allegory, become the leading theme of modern ornamentation, interpreted as a symbolic system that conveys an unreal, amazing and wonderful world. Modernism arose at the same time as symbolism - without much relevance to philosophical idealism or emotional symbolism, modernists used many stylistic forms designed by symbolists to give their art ideological significance. The quest for Art Nouveau artists is an attempt to create a personal mythological space by appealing to fantasy, elements of the mystical, immaterial, and, in some cases, the non-standard use of the primary principles of plastic language.

Key words: modern, stylization, ornamentation, fluoromorphic and zoomorphic motifs, symbolism, decor.

Актуальність теми досілдження. Модерн - стильовий напрям європейського та американського мистецтва 1890-1910-х рр., здійснивши помітний вплив на ідейно-творчі та пластичні пошуки в художньому просторі XX ст., у поліваріантності сучасного мистецтва набуває новаторського прочитання. Художники XXI ст., відроджуючи інтерес до різних історичних та культурих епох, переосмислюють та інтерпретують стилістичні особливості модерну з позиції індивідуального світобачення та світовідчуття. Це актуалізує дослідження проблематики стилізації модерну, як умовної, проте цілісної та спрямованої на формування нових структурних взаємозв'язків творчої переробки будь-яких природних форм та формоутворюючих принципів, оскільки деякі аспекти цього унікального явища не отримали ґрунтовного вивчення та осмислення.

Мета статті - проаналізувати символічне значення зооморфних, фрлороморфних, орнітоморфних та інсектоморфних мотивів декору стилю модерн, виявити специфіку орнаментальної стилізації.

Аналіз публікацій. Специфіка художнього стилю модерн та проблематика орнаменту викликає неабияку увагу серед наукової спільноти. Наприклад, Л. Стоілова та П. Іокімова в публікації «Симоліка прикрас у стилі Арт Нуво» («The Symbolism of Decorations in Art Nouveau Style») [8] досліджують особливості маскаронів; Ю. Івашко у монографії «Модерн Західної Європи, України і Китаю» [1] розглядає шляхи трансформації та імплементації стилю модерн відповідно до місцевих регіональних особливостей; І. Понкало в статті «Принципи та прийоми застосування архітектурного декору на будівлях Львова кінця XIX - початку XX ст.» [4] визначає домінуючі методи використання декору на львівських сецесійних будівлях та ін. Проте, не дивлячись на значний міждисциплінарний інтерес, проблематика орнаментальної стилізації стилю модерн вимагає подальшого дослідження.

Виклад основного матеріалу. Художній стиль модерн, роки формування та розвитку якого (1890-1914 рр.) співпадають з розпадом трьох великих європейських імперій - Австро-Угрської, Російської та Османської, на думку зарубіжних дослідників $є$ символом романтичного процесу самовизначення більшості європейських країн $[7,15]$.

Доба модерну нерідко асоціюється зі своєрідним протестом проти класичного матеріалізму та натуралізму, водночас характеризуючись протиставленням людських настроїв, уявлень про життя, естетику, роль мистецтва та його взаємовпливу з тогочасними суспільними проблемами. Саме естетизм стає генератором нового стилю, оскільки краса перетворилася на всезагальну, глобальну категорію, а її культивування набувало практично релігійних форм. Відповідно твори мистецтва, як безпосередні носії краси, наділялися здатністю реформувати життя за новим естетичним взірцем, на основі загальної гармонії та рівноваги.

Характерними цінностями модерну, що витікають з ідеалів символізму та імпресіонізму $є$ індивідуальне бачення художника, нематеріальність реального світу, акцентуація на візуальні (сенсорні) властивості об'єктів, а також на відображення або екстеріоризацію внутрішніх, суб'єктивних станів. Модерн закликає до єдності мистецтв, декорування всіх поверхонь - своєрідний культ внутрішнього, приватного простору тоді розглядався як святилище природи та жіночого, а також простір психології. Повертаючись до першоджерел, головна тенденція в стилі модерн наслідує кредо британських прерафаелітів (Братство художників, поетів та критиків У. Харна, Д. Мілле, Д. Россетті, У. Россетті, Д. Коллінсана, Ф. Стівенса та Т. Вулна, засноване в Англії у 1848 р.) [6, 42-50], що було спровоковано духовним та творчим холізмом середньовічної культури, втраченим у наступні історичні епохи. Ранні доктрини прерафаелітів підкреслюють істинне та ретельне вираження уважних споглядань за природою та виключають традиційні прояви виробництва - чиста душа, чистий розум та чиста уява в мистецтві є умовами того, щоб відчути природу, історію та Святе Євангеліє.

Відповідно світосприйняття митців модерну полягає в мовчазному діалозі души з природою моральне одкровення та унікальність глибинного творчого індивідуалізму $є$ символом цілісності з Всесвітом, що надає уявлення про реальність та художнє піднесення, нівелює звичні фрорми та створює 
нові. Одним із найрозповсюдженіших джерел натхнення за часів модерну стає небесна сила Світла, що «запліднює» Природу [8, 50].

Варто зауважити, що унікальність розвитку орнаментальної мови в декорі стилю модерн безпосередньо пов'язане з творчістю художників-прерафаелітів, англійських митців, теоретиків та практиків модерну - У. Морріса, Ч. Войзі, К. Дрессера, О. Бердслі та Ч. Макінтоша, а також членів товариства «Гільдія століття» С. Імейджа та А. Макмардо, які вперше застосували новаторські фрорми стилізації рослинного та зооморфного орнаменту. Характерним для мистеців модерну в процесі створення новітньої орнаменталістики було звернення до провідних художніх стилів минулого та стародавніх культур як до невичерпного джерела натхнення. Відомими європейськими стилізаторами природних мотивів для мистецтва модерну були К. Крумбгольц («Рослинний орнамент», 1878 р.), І. Штауффрагер («Малювання рослин, стилізованих та натуральних», 1897 р.), Р. фрон Гток («Рослини в мистецтві», 1896 р.) та ін. Стилізація, спрямована не лише на гіперболізацію та перевтілення найхарактерніших рис історичних стилів (наприклад, середньовіччя, готики та класицизму), а й на зміни природних (рослинних, зооморфних та ін.) і антропоморфних форм, набуваючи новаторського характеру в процесі самоствердження стилю, стає однією з головних тенденцій модерну, поєднавши реальне та умовне.

Можемо визначити кілька принципів створення декоративного орнаменту провідними художниками 1890-1910-х рр.:

- відповідність орнаментальної пластики стилеутворюючій лінії «удару батога» та створення композиції за законами динамічної рівноваги;

- створення орнаментальних композицій за законами статики (наприклад, геометричні композиції зі статичними мотивами та статично вирішеним середовищем);

- творча стилізація;

- орієнтування на органіку (перетворення досить нетипових органічних фрорм мохів, грибів, лишайників та ін.; збагачення традиційної орнаменталістики фрормами зів'ялих рослин; посилення інтересу до рослин, пов'язаних із містичними легендами та повір'ями, отруйних та підводних рослин);

- принцип уподібнення (традиційні для європейських країн квіти стилізуються під екзотичну східну фрлору).

Зауважимо, що ритмічний малюнок та кольорова ґама в мистецтві модерну сповнені глибинним та багатозначним сенсом. Наприклад, викривлена лінія (так звана «лінія життя» - антитеза прямій «лінії смерті») та рухомість форм були метафорою динамічного поштовху та оманливої стихії ірраціонального життєвого потоку. На думку дослідників, орнаментальна стилізація модерну уособлювала не лише єдність з природою, в якій відсутні прямі лінії, а й певне коло ідей та образів, породжених фрілософрією життя та поетикою символізму [2, 102].

Навіть форми геометричного орнаменту асоціюються з природними образами - візерунками на крилах метеликів, кораловими рифами, дивовижними хвилями, малюнками на камінні чи зрубах дерев, морозними візерунками на склі або інієм на траві, переплетінням павутиння, ритмом схиленого вербового гілля та ін. Новаторського осмислення в орнаменті модерну набуває фон, на якому навмисно фокусується увага, інколи він перетворюється на зображення (наприклад, шпалери Ч. Войзі «Тюльпани та птахи», 1896 р.). Усі зміни відбувалися на основі нових теорій та естетичних підходів, передусім тяжіння до міфічного, франтастичного, відчутного впливу східних культур, а також посиленні привабливості стихій. Декоративні елементи та симетрія, як принцип композиції, пов'язані з природним орнаментом, піднесенні ліній в русі, що перетворюється з мотивів на структурний елемент.

Варто зазначити, що стилізація елементів природи в декорі стилю модерн характерна як для архітектури, скульптури, так і для декоративно-прикладного чи ювелірного мистецтва. В офрормленні будівель використовувалися як зооморфні так і флороморфні мотиви, в тому числі й дивовижний світ океану (лобстери, водорості, мушлі, риби та ін.).

Модерн виник одночасно з символізмом - не маючи суттєвого відношення до філософського ідеалізму або емоційному символізму, модерністи використовували багато стилістичних форм розроблених символістами, аби надати своєму мистецтву ідеологічного значення.

Символіка модерну надзвичайно багата - алегорії та метафори походять з естетики загального художнього символізму, відображаючи уявне майбутнє життя, елементи язичницьких культів та езотерики. Водночас, характерними є й унікальні міфологічні інваріанти та класичні стилістичні риси, майстерно втілені в кольорах, матеріалах, об'ємах та формах. Митці прагнули закласти індивідуальне символічне значення, глибинний сенс в природну форму, наділяючи рослини, квіти, птахів та тварин специфічними алегоричними значеннями, передусім запозиченими з античної міфрології та загальновідомих сюжетів сакрального мистецтва. Внаслідок мистецтвознавчого аналізу художніх творів стилю модерн, можемо констатувати, що найпопулярнішими орнаментальними флороморфними мотивами декору були білі лілеї (вітраж в римському Chiesa Evangelica Metodista, Італія; мозаїка янгол із білими лілеями та соняшниками в церкві Eglise Saint-Etienne se Briare, Бріар,Франція); троянди (горельєф на будинку Ангуера в Реусі, Іспанія, 1905 р.; фреска в готелі Max Hallet, Брюсель, Бельгія; вітраж у Casina delle Civette, Рим, Італія); тюльпани, орхідеї, ірис (вітраж у будинку Мануеля Філіпа, Барселона, Іспанія; горельєф на Edificio Guridi, Більбао, Іспанія); аквілегії, нарцис, соняшник (горельєфи на 
будинку Gottstein store, Вроцлав, Польша; вітраж в церкві Святого Павла, Базель, Швейцарія); латаття, маки та чортополох (один із найпопулярніших рослинних мотивів, наприклад, горельєф Maison Бордо, Франція; керамічний барельєф Immeuble Le Chardons, Париж, Франція; вітраж в Casa Museu Lluis Domenech I Montaner, Канет-де-Мар, Іспанія), а рослинний орнамент широко представлено стилізованими в'юнкими рослинами, каштановими деревами та плющем, який був утіленням життєвої сили фрлори, символізував цілеспрямованість, впертість та безсмертя. Відповідно до дуальності модерну, що виявляється в живому та неживому, реальному та нереальному, латаття та орхідеї символізували загибель, смерть та страждання, тоді як соняшник - жагу до життя, що можемо вважати своєрідними семіотичними ілюстраціями суміжних періодів фрормування органіки.

На думку деяких дослідників, лілеї, відповідно до античної легенди про викрадення Аідом Персефонни, символізували трагічність, підкреслюючи контрастність людського буття - стихійність кохання та похмуру сторону життя $[3,68]$. Проте М. Соріна зауважує, що біла лілея (як і троянда), відповідно до християнської символіки, сприймалася як символ чистоти Богоматері, водночас асоціюючись 3 воскресінням Христа [5, 261]. Досить неоднозначне символічне значення має і квітка аквілегії (найчастіше даний мотив зустрічається у розписах ваз) : символ миру, семи мирських чеснот, Святого Духу (ії пелюстки символізують святі дари); чарівна квітка, що допомогає знайти шлях в інший світ у кельтській міфології; символ невірності та спокуси в Середньовіччі.

Провідними орнітоморфними образами модерну стають лебідь - символізував духовну чистоту, грацію, і водночас трагізм самопожертви; павич, який символізував мудрість та передбачливість, у поєднанні з містичною небезпекою - через велику кількість «очей» на опір"ї, вважалося, що павич може наврочити (наприклад, вітраж на стелі ліонської вілли Lumiere, Франція; вітраж палермської вілли Tasca, Італія); сова (нерідко у поєднанні з рослинним орнаментом, наприклад, сграфіто на будівлі Інституту Дідро, Брюсель, Бельгія). Популярним творчим прийомом модерну, характерним для художників, які використовували зооморфні мотиви виключно як знаки-символи, є перенесення образів реальних тварин, комах та птахів з природного середовища в уявний, нерідко містичний, світ, створений відповідно до індивідуального бачення митця.

Зауважимо, що типовим для декору модерну є поєднання флороморфних, орнітоморфних та інсектоморфнни мотивів, наприклад, вітражі з зображенням орла, павича та лілеї у римській церкві Chiesa Valdese; сграфіто птахи з соняшником на будівлі середньої школи Святого Хреста в Кобурі, Німеччина; фрріз на будівлі вілли Zur Sonnenblume, Арбон, Швейцарія; ящірки з трояндами та маскароном - горельєф на будинку по вул. Reinickstrabe, 11 (Дрезден, Німеччина); золотий соняшник та комахи - горельєф на будівлі школи в Гановері, Німеччина (Wilhelm-Raabe-Schule) та ін.

Особливу увагу митці європейського модерну приділяли зооморфним мотивам - передусім пропонуючи власне переосмислення образів драконів, бабок, метеликів, хамелеонів, ящірок, риб та морських коників, відповідно до розуміння природи як містичного, таємничого та казкового світу. Наприклад, мозаічна підлога в будинку відомого іспанського живописця та графріка, лідера національного модернізму Р. Касаса (Casa Casas-Carbo, Барселона, Іспанія); мозаїка на будівлі торгівельного дому Рікі (Riquethaus, Лейпціг, Німеччина); фігури драконів на шпилях будинку Рокамора (Casa Antoni i Marc Rocamora); барельєф з бабками та жабами на фрасаді будинку Emst-Alexandrinen-Volksbad (Koбург, Німеччина); саламандри та риби на фронтані Карла Борромейського (Відень, 1909 р., скульптор Й. Енгельгарт - один із засновників Сецессіону); керамічні ящірки та хамелеони на фасаді Maison Greber (Бове, Франція) та ін. Пошуки митців модерну - спроби створити особистий міфологічний простір зверненням до франтазії, елементів містичного, імматеріального, а подекуди нестандартного використання першооснов пластичної мови.

Наукова новизна. Проаналізовано орнаментальні мотиви декору стилю модерн; визначено передумови виникнення та розвитку флороморфного і геометричного орнаменту, принципи стилізації орнаментальних образів та їх символіку.

Висновки. Новаторство образів превалювало в творчості художників модерністів, які розробили новий колорит, форму, фактуру, а головне - унікальний орнамент, що став найхарактернішою ознакою стилю. Флороморфні, зооморфні, орнітоморфні, інсектоморфні, антропоморфні та геометричні мотиви, що вирізнялися відносною образністю та алегорією стають провідною тематикою орнаментики модерну, осмислюючись як система символів, що передає світ нереальний, дивовижний та прекрасний.

\section{תimepamypa}

1. Ивашко Ю. Модерн Западной Европы, Украины и Китая : пути трансформации и имплементации. Киев : Феникс, 2015. 152 с.

2. Кириков Б. М. Петербургский модерн. Заметки об архитектуре и монументально-декоративном искусстве. Панорама искусств. 1987. № 10. С. 99-148.

3. Королева С. В., Кошелева А. А. История стиля модерн. Особенности художественной образности предметного убранства интерьера и декоративно-прикладного искусства. Известия Тульского государственного университета. Серия Гуманитарные науки. 2013. Вып. 1. С. 67-71.

4. Понкало С. І. Принципи та прийми застосування архітектурного декору на будівлях Львова кінця XIX початку XX ст. Сучасні проблеми архітектури та містобудування. 2016. Вип. 45. С. 98-108. 
5. Сорина М. О. Цвет и символ в искусстве, дизайне и архитектуре. Москва : МарТ, 2003. 288 с.

6. Frampton K. Modern Architecture. A Critical History. London, T \& H, 1992. 376 p.

7. Iokimov P., Stoilova L. Sezession and Bulgarian Architecture. Lexicon. Time \& beauty. Art Nouveau In The Bulgarian Cities. Collina V. (Ed.), 2014, pp. 18-25.

8. Stoilova L., lokimov P. The Symbolism of Decorations in Art Nouveau Style. Arhitektura. 2014. № 4. pp. 4955. URL : http://20c-arch-bg.blogspot.com/2015/01/six-months-11072014-11012015.html.

\title{
References
}

1. Ivashko, Yu. (2015). Modern of Western Europe, Ukraine and China: ways of transformation and implementation. Kiev: Phoenix [in Russian].

2. Kirikov, B. M. (1987). Petersburg Modern. Notes about architecture and monumental-decorative art. Panorama of the arts, no. 10, pp. 99-148 [in Russian].

3. Koroleva, S. V., Kosheleva, A. A. (2013). A History of Art Nouveau. Features of the artistic imagery of the subject decoration of the interior and decorative arts. News of Tula State University, issue 1, pp. 67-71 [in Russian].

4. Pankalo, S. I. (2016). Principles and acceptance of application of architectural decoration on buildings of Lviv of the end of XIX - beginning of XX century. Modern Problems of Architecture and Urban Development, issue 45, pp. 98-108 [in Ukrainian].

5. Sorina, M. O. (2003). Color and symbol in art, design and architecture. Moscow: March [in Russian].

6. Frampton, K. (1992). Modern Architecture. A Critical History. London, T \& H [in English].

7. lokimov, P., Stoilova, L. (2014). Sezession and Bulgarian Architecture. Lexicon. Time \& beauty. Art Nouveau In The Bulgarian Cities. Collina V. (Ed.), pp. 18-25 [in English].

8. Stoilova, L., lokimov, P. (2014). The Symbolism of Decorations in Art Nouveau Style. Arhitektura. 2014. № 4. pp. 49-55. URL : http://20c-arch-bg.blogspot.com/2015/01/six-months-11072014-11012015.html [in Bulgarian].

Стаття надійшла до редакції 04.11.2019 р. Прийнято до публікації 22.11.2019 р.

УДК 793. $38(4-11) « 18 »$

Павлюк Тетяна Сергіївна

кандидат мистецтвознавства, доцент

Київського національного університету культури і мистецтв

24caratsofart@gmail.com

ORCID 0000-0002-3940-9159

\section{СТАНОВЛЕННЯ ТА ТЕНДЕНЦІЇ РОЗВИТКУ СПОРТИВНОГО БАЛЬНОГО ТАНЦЮ В НІМЕЧЧИНІ}

\begin{abstract}
Мета статті - виявити внесок німецьких танцюристів та вчителів танців у становлення спортивних бальних танців; охарактеризувати специфіку розвитку конкурсного танцювального руху в Німеччині та діяльність танцювальних організацій в XX ст. Методологія дослідження. 3 огляду на багатоаспектність означеної проблематики дослідження має комплексний міждисциплінарний характер. Застосовано загальнонаукові та мистецтвознавчі методи: історичний (для вивчення історичного періоду формування конкурсного бального танцю в Німеччині), аксіологічний (для об'єктивного визначення та аргументації впливу діяльності німецьких танцювальних організацій на становлення конкурсного бального танцю як організованого виду спорту), метод біографічної реконструкції (для детального відтворення фррагментів біографрії провідних німецьких танцюристів і вчителів танцю XX ст.), що дозволило осмислити специфріку розвитку конкурсного танцювального руху в Німеччині та процес становлення спортивних бальних танців в історичні ретроспективі. Наукова новизна. Проаналізовано діяльність німецьких танцюристів та вчителів танців XX ст. у контексті формування та становлення спортивного бального танцю. Виявлено вплив німецьких організацій («Рейхської асоціації сприяння розвитку соціальних танців» та «Міжнародної фредерації аматорського танцю») на становлення конкурсного бального танцю як організованого виду спорту. Висновки. Мистецтвознавче дослідження специфіки розвитку конкурсного бального танцю в Німеччині (1910-1990-ті рр.) виявило внесок німецьких танцюристів у процес кодифікації Міжнародного стилю бальних танців, зародження та становлення ансамблевого способу виконання танцювальних програм - формейшн. Виявлено, що протягом XX ст. представники Німеччини здійснили важливі перетворення в бальному танці, посприявши його поступовому становленні як організованого виду спорту, визначенню норм та концепцій управління на міжнародному рівні.
\end{abstract}

Ключові слова: бальні танці, спортивний бальний танець, німецькі танцювальні організації, танцювальні турніри.

Павлюк Татьяна Сергеевна, кандидат искусствоведения, доцент Киевского национального университета культуры и искусств

Становление и тенденции развития спортивных бальных танцев в Германии

Цель статьи - выявить вклад немецких танцоров и учителей танцев в становление спортивных бальных танцев; охарактеризовать специфику развития конкурсного танцевального движения в Германии и деятельность танцевальных организаций в XX в. Методология исследования. Учитывая многоаспектность указанной пробле-

() Павлюк Т. С., 2020 